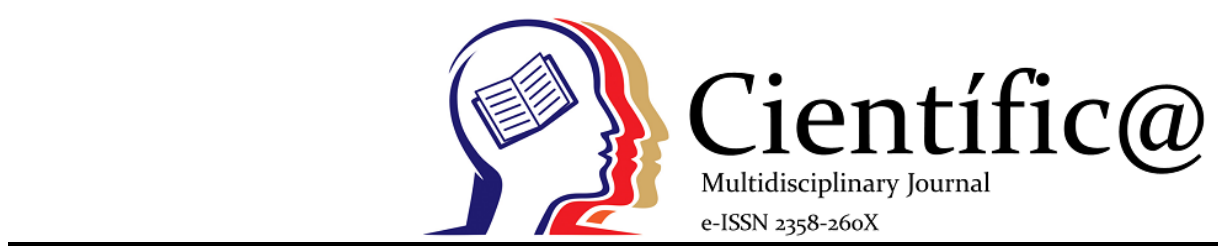

\title{
ANTIFUNGAL AND ANTIBACTERIAL ACTIVITY OF THE FLORAL ETHANOLIC EXTRACT OF MANDEVILLA POHLIANA (STADELM.) A. H. GENTRY
}

\author{
ATIVIDADE ANTIFÚNGICA E ANTIBACTERIANA DO EXTRATO ETANÓLICO FLORAL DE MANDEVILLA \\ POHLIANA (STADELM.) A. H. GENTRY
}

Antonio Carlos Pereira de Menezes Filho ${ }^{1}$, Matheus Vinícius Abadia Ventura ${ }^{2}$, Carlos Frederico de Souza Castro ${ }^{3}$, Frederico Antonio Loureiro Soares ${ }^{4}$, Marconi Batista Teixeira ${ }^{5}$

${ }^{1} \mathrm{PhD}$ student in Agricultural Sciences at Goiano Federal Institute - astronomoamadorgoias@gmail.com
${ }^{2} \mathrm{PhD}$ student in Agricultural Sciences at Goiano Federal Institute - matheusvinicius10@hotmail.com
${ }^{3} \mathrm{PhD}$ professor at the Goiano Federal Institute - carlosfscastro@gmail.com
${ }^{4} \mathrm{PhD}$ professor at the Goiano Federal Institute - frederico.soares@ifgoiano.edu.br
${ }^{5} \mathrm{PhD}$ professor at the Goiano Federal Institute - marconi.teixeira@ifgoiano.edu.br

\section{Info}

Recebido: 04/2021

Publicado: 06/2021

DOI: $10.37951 / 2358-260 X .2021 v 8 i 1.5625$

ISSN: 2358-260X

Palavras-Chave

Apocynaceae. Gênero Mandevilla.

Escherichia coli. Gênero Candida.

Keywords:

Apocynaceae. Mandevilla Genus.

Escherichia coli. Candida Genus.

\section{Resumo}

Mandevilla pohliana é uma espécie pertencente à família Apocynaceae encontrada em ambientes de Cerrado. Objetivou-se avaliar neste estudo, a ação antifúngica e antibacteriana do extrato etanólico floral de M. pohliana. Flores frescas de M. pohliana foram coletadas e o extrato etanólico produzido por maceração. Em diferentes concentrações de extrato, foram determinadas as atividades antifúngicas sobre o gênero Candida, e antibacterianas sobre Escherichia, Salmonella, Enterococcus, Pseudomonas e Staphylococcus. Foi observada atividade de antibiose apenas para C. guilliermondii com 9-2 mm, para $P$. aeruginosa com $12-3 \mathrm{~mm}$ e para E. faecalis entre 10-3 mm nas maiores concentrações entre 50$500 \mathrm{mg}$ mL-1. 0 extrato etanólico floral de Mandevilla pohliana demonstrou potencial como agente antifúngico e antibacteriano natural.

\section{Abstract}

Mandevilla pohliana is a species belonging to the Apocynaceae family found in Cerrado environments. The objective of this study was to evaluate the antifungal and antibacterial action of the floral ethanolic extract of M. pohliana. Fresh flowers of M. pohliana were collected and the ethanolic extract was produced by maceration. In different concentrations of extract, antifungal activities on the genus Candida were determined, and antibacterial activities on Escherichia, Salmonella, Enterococcus, Pseudomonas and Staphylococcus. Antibiosis activity was observed only for $C$. guilliermondii with 9-2 mm, for P. aeruginosa with 12-3 mm and E. faecalis between 10-3 mm at the highest concentrations between 50-500 mg mL-1. The floral ethanolic extract of Mandevilla pohliana showed potential as a natural antifungal and antibacterial agent.

\section{INTRODUCTION}

The Apocynaceae family has numerous botanical genera, among which, Mandevilla Lindl stands out. belonging to the Mesechiteae Tribe, widely distributed in zones of neotropical climate, presenting 150 species distributed from Central America to South America. The species inserted in the genus Mandevilla, are found in very varied natural environments such as desert, forests, tepuis, open pastures, and in particular $M$. pohliana (Fig. 1) in areas the cerrado domain, rupestrian fields, and restingas in Brazil, flourishing between September to July (SIMÕES et al., 2006; MONGUILHOTT; MELLO-SILA, 2008; DUARTE; LARROSA, 2011).

In general, the Mandevilla genus is composed of shrubs, sub-shrubs or lianas, which produce whitish latex, sometimes presenting a root system (xylopodium); the branches are glabrous or hairy; 
opposite leaves, rarely verticilated, petiolate or sessile; lateral and axillary or terminal inflorescences, simple racemes, rarely composed; and fruits with comosa seeds (MONGUILHOT'T; MELLO-SILA, 2008).

Phytochemical researches with Mandevilla were gathered and described in the study by Duarte and Larrosa (2011) where they include the considerable presence of groups of phytomolecules such as cardiac glycosides, steroids, and triterpenoids, oleic and linoleic acids, acetylilustrol, pregnanos glycosides, velutinoside A and velutinol A. However, there are few studies with M. pobliana (MARTINS; ALVES, 2008; VITAL, 2019), and there are no studies with biological activities from the flower of $M$. pobliana, making it necessary to know and elucidate the phytochemical profile and potentials biological activities.

The aim of this work was to evaluate the floral ethanolic extract of $M$. pobliana with antifungal and antibacterial activity in different concentrations.

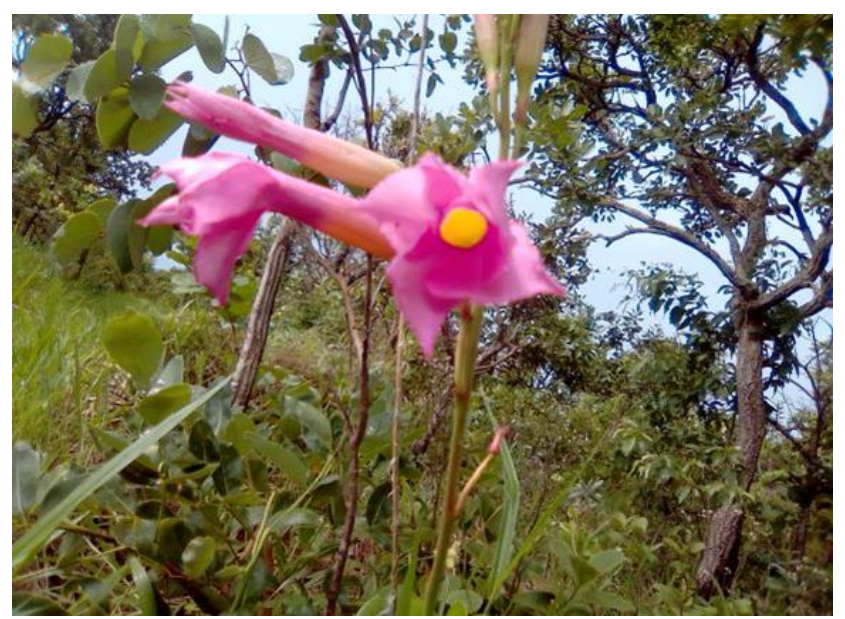

Figure 1. Mandevilla pobliana in flowering period in the Cerrado domain, phytophysiognomy restricted sense. Source: Authors, 2020.

\section{MATERIAL AND METHODS}

\section{Plant material}

Fresh flowers of $M$. pohliana were collected in the municipality of Rio Verde $\left(17^{\circ} 47^{\prime} 10.9^{\prime \prime} \mathrm{S}\right.$ and $50^{\circ}$ 58 '02.0" W), at the University of Rio Verde, Goiás, Brazil. The species was identified and deposited at the
Herbarium of the Goiano Federal Institute, Goiás, Brazil, with the voucher (number HRV 10090).

\section{Extract production}

Fresh flowers of $M$. pobliana were added in $98 \%$ ethanol. The extract was produced by maceration for five days. After this period, the solvent was extracted in a rotary evaporator with negative pressure and a temperature of $50{ }^{\circ} \mathrm{C}$. The extract was then kept at -12 ${ }^{\circ} \mathrm{C}$ and lyophilized.

\section{Antifungal and antibacterial activity}

The microbiological test followed as described by Vieira et al. (2019) modified, using the paper disk diffusion technique, and the results expressed in ( $\mathrm{mm})$. Strains of Candida albicans (ATCC 10231), Candida tropicalis (ATCC 4563), Candida guilliermondii (ATCC 90877), Candida krusei (ATCC 34135), Pseudomonas aeruginosa (ATCC 27853), Escherichia coli (ATCC 25922), Staphylococcus aureus (ATCC 25923), Enterococcus faecalis (LB29212), Salmonella serovar Enteritidis (ATCC 13076) and Salmonella serovar Typhimurium (ATCC 14028).

The activation of the microorganisms was carried out in a sterile solution of $\mathrm{NaCl}$ conc. $0.85 \%$ until reaching the degree of 0.5 on the scale MacFarland conc. $\left(1 \times 10^{4} \mathrm{CFU} \mathrm{mL}-1\right) .10 \mathrm{~cm}$ Petri dishes were prepared with sabouraud dextrose agar (SDA) for the antifungal assay, and for the bacterial assay with mueller hinton agar (MHA) after sterilization.

The Petri dishes containing a specific medium were inoculated using a sterile swab soaked with the microbial suspension and spread throughout the plate. Filter paper discs with a diameter of $7 \mathrm{~mm}$ were impregnated with $100 \mu \mathrm{L}$ of the extract in different concentrations $(500,200,50,25$, and $5 \mathrm{mg} \mathrm{mL}-1)$, as a negative control, saline solution with 10\% DMSO $(v / v)$ and a disk containing a 10\% $(v / v)$ DMSO solution, and as a positive control disc with antimicrobial agents, for 
bacteria Azithromycin (15 $\mu \mathrm{g})$, Cephalexin (30 $\mu \mathrm{g})$, Tigecycline $(15 \mu \mathrm{g})$ and Amikacin $(30 \mu \mathrm{g})$, and fungal ketoconazole $(50 \mu \mathrm{g})$.

The Petri plates were incubated at $36{ }^{\circ} \mathrm{C}$ with an interval between 24-36 hours, after that period, the halo of antibiosis when present was measured with a digital caliper. The tests were carried out in triplicate.

\section{Statistical analysis}

The arithmetic mean was determined followed by \pm standard deviation. The Tukey's test $(P \leq 0.05)$ was used when there is a significant difference between the concentrations and patterns of antibacterials and antifungal agents, using the $P A S T 3$ program.

\section{RESULTS AND DISCUSSISON}

Numerous fungi and pathological bacteria have acquired resistance to the main antimicrobial agents. And this is a serious problem since the widely used antifungals and antibacterials no longer have the effect of antibiosis. Evaluating the floral ethanolic extract of M. pobliana (Table 1), it was found that only the strain of C. guilliermondii was sensitive to the extract in the two highest concentrations of 500-200 $\mathrm{mg} \mathrm{mL}^{-1}$ with an inhibitory effect of 9 and $2 \mathrm{~mm}$. For the antibacterial assay, the extract demonstrated potential bacteriostatic activity on $P$. aeruginosa between 12-3 $\mathrm{mm}$ between concentrations $500-50 \mathrm{mg} \mathrm{mL}^{-1}$, a similar effect was observed for E. faecalis with inhibition of $10-3 \mathrm{~mm}$ in the three highest concentrations.

Evaluating the floral ethanolic extract of $M$. pobliana (Table 1), it was found that only the strain of $C$. guilliermondii was sensitive to the extract in the two highest concentrations of 500-200 $\mathrm{mg} \mathrm{mL}^{-1}$ with an inhibitory effect of 9 and $2 \mathrm{~mm}$. For the antibacterial assay, the extract demonstrated potential bacteriostatic activity on $P$. aeruginosa between 12-3 $\mathrm{mm}$ between concentrations $500-50 \mathrm{mg} \mathrm{mL}^{-1}$, a similar effect was observed for E. faecalis with inhibition of $10-3 \mathrm{~mm}$ in the three highest concentrations.

All results when positive showed a statistical difference between them and the three antibacterial agents and a reference antifungal agent using the Tukey's test with $(P \leq 0.05)$.

Table 1. Antimicrobial activity of the floral ethanolic extract of Mandevilla pobliana.

\begin{tabular}{|c|c|c|c|c|c|c|c|c|c|}
\hline \multirow[b]{2}{*}{ Microorganisms } & & \multicolumn{8}{|c|}{ Growth inhibition zone (mm) } \\
\hline & 500 & 200 & 50 & 25 & 5 & $\begin{array}{c}\text { Disc } \\
15 \mu g^{a}\end{array}$ & $\begin{array}{c}\text { Disc } \\
30 \mu g^{b}\end{array}$ & $\begin{array}{c}\text { Disc } \\
15 \mu g^{c}\end{array}$ & $\begin{array}{c}\text { Disc } \\
50 \mu g^{d}\end{array}$ \\
\hline C. albicans & - & - & - & - & - & & & & 26 \\
\hline C. Krusei & - & - & - & - & - & & & & 28 \\
\hline C. guilliermondii & $9 \mathrm{~b}$ & $2^{c}$ & - & - & - & & & & $24^{\mathrm{a}}$ \\
\hline C. tropicalis & - & - & - & - & - & & & & 29 \\
\hline P. aeruginosa & $12^{\mathrm{b}}$ & $8^{b}$ & $3 \mathrm{c}$ & - & - & $20^{\mathrm{a}}$ & $22 * * a$ & nd & \\
\hline E. coli & - & - & - & - & - & 19 & $20^{*}$ & nd & \\
\hline S. aureus & - & - & - & - & - & 24 & $27 *$ & nd & \\
\hline E. faecalis & $10^{\mathrm{b}}$ & $7 \mathrm{~b}$ & $3 \mathrm{cb}$ & - & - & $20^{a}$ & nd & $22^{\mathrm{a}}$ & \\
\hline S. Enteritidis & - & - & - & - & - & 28 & $25^{*}$ & nd & \\
\hline S. Typhimurium & - & - & - & - & - & 29 & $28 *$ & nd & \\
\hline
\end{tabular}

Extract concentration determined in $\mathrm{mg} \mathrm{mL}^{-1}$. (-) There was no halo formation. Nd No determined. Azithromycin disc $^{a}$. Cephalexin disc ${ }^{b *}$. Amikacin disc ${ }^{b * *}$. Tigecycline disc ${ }^{c}$. Ketoconazole disc ${ }^{\mathrm{d}}$. Source: Authors, 2021.

There are no studies in the literature on antifungal and antibacterial activity for $M$. pohliana, the few studies like that by Carpinella et al. (2010) describe brief essays on both biological actions, although they have not verified an effective fungistatic action on Fusarium verticillioides from the extracts of $M$. laxa and $M$. 
pentlandiana. Moderate antibacterial activity on $P$. aeruginosa, Mycobacterium phlei, Bacillus subtilis, E. faecalis and $S$. aureus were observed from the leaf ethyl acetate extract of $M$. veraguasensis in the study by Abad-Reyes et al. (2006).

According to Sampaio et al. (2021), the Mandevilla genus has several pharmacological applications as venom inhibition, anti-edematogenic and anti-inflammatory activity (BIONDO et al., 2003; MATTOOS et al., 2006; ALMEIDA et al., 2017). Thus, it is important to highlight the main biological and pharmacological properties described in the literature was antibacterial and bacteriostatic activity like flavonoids, organic acids, tannins, triterpenoids, phenols, and alkaloids (DUARTE et al., 2014; BARCELOS et al., 2017; CARVALHO et al., 2020; SANTOS et al., 2020).

Subsequent studies should be carried out by assessing the minimum inhibition concentration (MIC) assay for pathological agents that have been shown to be sensitive at the usual doses in this study. It is also suggested, that even if there is no inhibition to the other agents by the concentrations evaluated, it does not mean that the extract does not present such an inhibitory action, and should be evaluated in concentrations higher than those recommended in this work, as well as an analysis of the phytochemical profile of this floral extract.

\section{CONCLUSION}

It is concluded that the floral ethanolic extract of M. pobliana, has a potential antifungal and antibacterial activity for most of the tested strains.

\section{ACKNOWLEDGEMENTS}

We thank to Goiano Federal Institute, to Technological Chemistry, Agricultural Microbiology, and Herbarium, and research funding agencies CAPES, FAPEG, CNPq and FINEP.

\section{REFERENCES}

Abad-Reyes A, Bahsas A, Delgado-Méndez P, AmaroLuis JM, Towers GHN. Actividad antimicrobiana y estudio fitoquímico preliminar de Mandevilla veraguasensis (Seem.) Helms. (Apocynaceae). Avances Química. 2006; 1(3): 29-34.

https: / $/$ www.redalyc.org/articulo.oa?id $=93310$ $\underline{304}$

Almeida DA, Rosa SI, Cruz TC, Pavan E, Sabino Damazo A, Soares IM, Ascencio SD, Macho A, Martins DT. Mandevilla longifora (Desf.) Pichon improves airway inflammantion in a murine model of allergic asthma. J Ethnopharmacol. 2017; 200: 51-59. https://doi.org/10.1016/i.jep.2017.02.015

Barcelos IB, Bulian AL, Calazans RSP, Degen NA, Alves LO, Sobral FOS, Salvi JO. Análise fitoquímica e das atividades citotóxica, antioxidante, e antibacteriana das flores de Tabebuia serratifolia (Vahl.) Nicholson. Revista Fitos. 2017; 11(1): 9-23. https://www.arca.fiocruz.br/handle/icict/2111 $\underline{5}$

Biondo R, Pereira AMS, Marcussi S, Pereira PS, França SC, Soares AM (2003) Inhibition of enzymatic and pharmacological activities of some snake venoms and toxins by Mandevilla velutina (Apocynaceae) aqueous extract. Biochimie. 2003; 85(10): 1017-1025. https://doi.org/10.1016/s0300-9084(03)00138$\underline{x}$

Carpinella MC, Ruiz G, Palacios SM. Screening of native plants of central Argentina for antifungal activity. Allelopathy J. 2010; 25(2): 423-432.

Carvalho GG, Peres GC, Mendonça RMC, Santos Filho EX. Phytochemical prospection and antibacterial activity of native plants from the cerrado of goiás, Brazil. J Pharmaco Phytochem. 2020; 9(2): 29-37.

Duarte JL, Mota LJ, Almeida SSMS. Análise fitoquímica das folhas de Tabebuia serratifolia (Vahl) Nicholson (ipê amarelo). Estação Científica. 2014; 4(1): 33-43. 
https://periodicos.unifap.br/index.php/estacao Larticle/view/1265/jonatasv4n1.pdf

Duarte MR, Larrosa CRR. Morpho-anatomical characters of the leaf and stem of Mandevilla coccinea (Hook. et Arn.) Woodson, Apocynaceae. Braz J Pharmaceut Sci. 2011; 47(1): 137-144. http://dx.doi.org/10.1590/S198482502011000100017

Martins S, Alves M. Aspectos anatômicos de espécies simpátridas de Mandevilla (Apocynaceae) ocorrentes em inselbergues de Pernambuco Brasil. Rodriguésia. 2008; 59(2): 369-380. http://dx.doi.org/10.1590/2175$\underline{7860200859209}$

Mattos WM, Campos MM, Fernandes ES, Richetti GP, Niero R, Yunes RA, Calixto JB (2006) Antiedematogenic effects of velutinol $\mathrm{A}$ isolated from Mandevilla velutina: evidence for a selective inhibition of kinin B1 receptor-mediated responses. Regul Pept. 2006; 136(1-3): 98-104. https://doi.org/10.1016/i.regpep.2006.04.011

Monguilhott L, Mello-Sila R. Apocynaceae do parque estadual de Ibitipoca, Minas gerais, Brasil. Bol Botânica Uni São Paulo. 2008; 26(2): 93-130. https://www.jstor.org/stable/42871689

Sampaio MTG, Fernandes CM, Souza GGP, Carvalho ES, Velasco JAC, Silva JCM, Alves OC, Ponzio EA. Evaluation of aqueous extract of Mandevilla fragrans leaves as environmental-friendly corrosion inhibitor for mild steel in acid medium. J Bio Tribo-Corrosion. 2021; (7): 7-14. https://doi.org/10.1007/s40735-020-00445-9
Santos TA, Abreu JA, Torres TL. Avaliação das características físico-químicas, atividade antioxidante e fenólicos totais da farinha do extrato da jabuticaba (Myrciaria jaboticaba). Multidisciplinary J. 2020; 8(2): 1-13. https://doi.org/10.37951/2358260X.2020v7i2.4730

Silva KB, Pinheiro CTS, Soares CRM, Souza MA, Matos-Rocha TJ, Fonseca AS, Pavão JMSJ, Costa JG, Costa JG, Pires LLS, Santos AF. Phytochemical characterization, antioxidant potential and antimicrobial activity of Averrboa carombola L. (Oxalidaceae) against multiresistant pathogens. Braz J Biol. 2021; 81(3): 509-515. https://doi.org/10.1590/1519-6984.220259

Simões AO, Endress ME, Niet T, Kinoshita LS, Conti E. Is Mandevilla (Apocynaceae, Mesechiteae) monophyletic? Evidence from five plastid DNA loci and morphology. Ann M Botanical Garden. 2006; 93(4): 565-591. https://doi.org/10.3417/00266493(2006)93[565:IMAMME]2.0.CO;2

Vieira PRN, Reis DRML, Oliveira CT, Souza CRN. Atividade antimicrobiana das lactonas sesquiterpênicas da folha de yacón (Smallanthus sonchifolius, Asteraceae). Rev Fitos, 2019. https://revistafitos.far.fiocruz.br/index.php/re vista-fitos/article/view/864/765

Vital FAZ. Occurence of species of Mandevilla Lindl. (Apocynaceae Juss.: Apocynoideae) in Lavras (MG), Brazil: ecological and taxonomical implications. Scientif Electro Archives. 2019; 12(4):

75-80. 